\title{
Penerapan Pasal 1 Huruf B Undang-Undang Nomor 35 Tahun 2008 Terhadap Penyelenggaraan Pemerintahan Daerah Provinsi Papua Barat
}

\author{
A. Sakti Ramdhon Syah R. \\ Fakultas Hukum, Universitas Muhammadiyah Sorong \\ Email : Ramdhansyah44@gmail.com
}

\begin{abstract}
Abstrak
Penelitian ini bertujuan untuk menganalisis bagaimana penyelenggaran pemerintahan daerah berdasarkan Otonomi Khusus menurut Undang-Undang nomor 35 tahun 2008, serta, bagaimana Kedudukan dan Penyelenggaraan Pemerintahan Daerah Provinsi Papua Barat Berdasarkan Undang-Undang Nomor 35 Tahun 2008. Penelitian ini menggunakan metode penelitian hukum normatif-yuridis yang mengacu pada norma hukum segala peraturan perundang-undangan yang relevan dengan judul penelitian, dengan pendekatan kualitatif. Sifat penelitian ini bersifat deskriptif-analistis. Hasil penelitian ini menunjukan, kerancuan redaksi ketentuan Pasal 1 huruf b berdasarkan kaidah pembentukan peraturan-perundang-undangan belumlah dapat dikatakan telah memenuhi kaidah pembentukan peraturan perundang-undangan yang baik. Di lain sisi, kedudukan dan penyelenggaraan pemerintahan daerah Provinsi Papua Barat berdasarkan peraturan perundang-undangan dapat dikatakan legitimatif. Kedudukan Provinsi Papua Barat dalam penyelenggaraan pemerintahan daerah berdasarkan Otonomi Khusus menurut UU Otsus jo. Perpu Nomor 1 Tahun 2008, dalam Konsideran menimbang disebutkan secara tegas bahwa keberadaan Provinsi Irian Jaya Barat yang kemudian berubah menjadi Provinsi Papua Barat, dalam kenyataannya telah menjalankan urusan pemerintahan dan pembangunan serta memberikan pelayanan kepada masyarakat sejak tahun 2003, namun belum diberlakukan Otonomi Khusus berdasarkan Undang-Undang Nomor 21Tahun 2001 tentang Otonomi Khusus Bagi Provinsi Papua.
\end{abstract}

Kata Kunci : Hukum Tata Negara, Otonomi Khusus Papua, Hukum Pemerintahan Daerah

\section{PENDAHULUAN}

Sejak disahkan pada tanggal 21 November tahun 2001 oleh Presiden Megawati Soekarno Putri, Provinsi Irian Jaya yang berubah nama menjadi Provinsi Papua diberikan kewenangan Otonomi Khusus dalam kerangka Negara Kesatuan Republik 
Indonesia. Disebutkan dalam Pasal 1 huruf b Undang-Undang Nomor 21 tahun 2001 tentang Otonomi Khusus Bagi Provinsi Papua, Otonomi Khusus adalah kewenangan khusus yang diakui dan diberikan kepada Provinsi Papua untuk mengatur dan mengurus kepentingan masyarakat setempat menurut prakarsa sendiri berdasarkan aspirasi dan hak-hak dasar masyarakat Papua.

Kebijakan pemerintah pusat dalam memberikan kewenangan berupa Otonomi Khusus Papua juga memberikan konstruksi sistem pemerintahan yang khusus dengan terbentuknya lembaga Majelis Rakyat Papua (MRP) sebagai representasi kultural orang asli papua dengan sejumlah kewenangan tertentu, serta Dewan Perwakilan Rakyat Papua (DPRP) sebagai sebuah lembaga yang memegang kekuasaan legislatif daerah Provinsi Papua. Terdapat pula Peraturan Daerah Khusus (Perdasus) yang dibentuk dalam rangka melaksanakan pasal-pasal tertentu dari Undang-Undang Nomor 21 tahun 2001, disamping adanya Peraturan Daerah Provinsi (Perdasi) dalam rangka pelaksanaan kewenangan sebagaimana diatur dalam peraturan perundangundangan.

Pemberian kewenangan Otonomi Khusus bagi masyarakat Papua diharapkan mampu mengakomodir sekurang-kurangnya 3 (tiga) unsur yang prinsipil yaitu, (i) Perlindungan, yang meliputi, pengakuan kepada masyarakat hukum adat, hak pemanfaatan Sumber Daya Alam, peradilan adat, pemerintahan adat sebagai suatu identitas lokal, dan penyelesaian terhadap masalah sosial-politik dan hak asasi manusia; (ii) Keberpihakan, meliputi, kebutuhan orang asli papua terhadap akses pendidikan, kesehatan, partisipasi, ataupun kesejahteraan; dan (iii) Pemberdayaan, meliputi, pembangunan baik fisik maupun fisik seperti infrastruktur, keterisolasian, ataupun transportasi.

Pada tahun 2008, Undang-Undang Nomor 21 tahun 2001 diubah dengan Peraturan Pemerintah Pengganti Undang-Undang (Perpu) Nomor 1 tahun 2008, dan kemudian disahkan menjadi Undang-Undang Nomor 35 tahun 2008 tentang Penetapan Peraturan Pemerintah Pengganti Undang-Undang Nomor 1 Tahun 2008 Tentang Perubahan Atas Undang-Undang Nomor 21 Tahun 2001 Tentang Otonomi 
Khusus Bagi Provinsi Papua Menjadi Undang-Undang (selanjutnya disebut UU Otsus). Dalam konsideran menimbang Undang-Undang ini, disebutkan bahwa urgensi dalam UU Otsus menyangkut masalah kejelasan status dan kepastian hukum Provinsi Papua Barat dalam penyelenggaraan pemerintahan agar tidak menimbulkan hambatan percepatan pembangunan khususnya bidang sosial, ekonomi, dan politik serta infrastruktur di Provinsi Papua Barat.

UU Otsus dalam memberikan kejelasan status dan kepastian hukum kepada Papua barat, mengganti redaksi dalam Pasal 1 huruf a dengan menambahkan frasa "Papua Barat". Selain memberikan kejelasan status dan kepastian hukum terhadap Provinsi Papua Barat, dalam konsideran menimbang UU Otsus, juga disebutkan bahwa keberadaan Provinsi Irian Jaya Barat yang kemudian berubah menjadi Provinsi Papua Barat, dalam kenyataannya telah menjalankan urusan pemerintahan dan pembangunan serta memberikan pelayanan kepada masyarakat sejak tahun 2003 , namun belum diberlakukan Otonomi Khusus berdasarkan Undang-Undang Nomor 21 tahun 2001 tentang Otonomi Khusus Bagi Provinsi Papua. Dengan kata lain, dasar perumusan UU Otsus didasarkan pada eksistensi Papua Barat dalam penyelenggaran pemerintahan, dan untuk itu diperlukan pemberian kewenangan otonomi Khusus.

Akan tetapi dalam Pasal 1 huruf b UU Otsus yang menguraikan tentang pengertian "Otonomi Khusus", hanya mengatur tentang kewenangan Otonomi Khusus kepada Provinsi Papua untuk mengatur dan mengurus kepentingan masyarakat. Tidak ditemukan adanya frasa "Papua Barat" sebagai Provinsi yang juga diberikan kewenangan khusus dan diakui sebagaimana tertuang dalam Pasal 1 huruf a UU Otsus. Pengaturan ini mengakibatkan beberapa kerancuan, yakni, ketidaktegasan Pasal 1 huruf b UU Otsus yang tidak memuat frasa "Papua Barat" sebagai wilayah pemerintahan dengan kewenangan khusus yang diakui sebagaimana diberikan kepada Provinsi Papua.

Di samping itu, UU Otsus tidak secara tegas memberikan pengaturan operasionalisasi tentang kedudukan MRP(B) dan DPRP(B), apakah kedudukannya adalah sama seperti kedudukan MRP dan DPRP di Provinsi Papua, termasuk tata cara 
pemilihan anggota-anggotanya. Permasalahan terhadap operasionalisasi UU Otsus terhadap eksistensi pemerintahan Provinsi Papua Barat dapat pula merambat ke sejumlah persoalan lain, misalnya, mengenai mekanisme pemberian pertimbangan, persetujuan, dan penetapan Perdasus Papua Barat sebelum diberlakukan.

Berdasarkan uraian diatas, maka dapat dikemukakan 2 (dua) rumusan masalah sebagai berikut : (1) Bagaimana penyelenggaraan pemerintahan daerah berdasarkan Otonomi Khusus menurut Undang-Undang Nomor 35 tahun 2008 ?; (2) Bagiamana Kedudukan dan Penyelenggaraan Pemerintahan Daerah Provinsi Papua Barat Berdasarkan Undang-Undang Nomor 35 Tahun 2008

\section{PEMBAHASAN}

\section{Penyelenggaraan Pemerintahan Daerah Berdasarkan Otonomi Khusus Menurut Undang-Undang Nomor 35 Tahun 2008}

Dasar Konstitusionalitas mengenai penyelenggaraan pemerintahan daerah diatur dalam Pasal 18 UUD NRI 1945 yang menegaskan pula bagaimana kedudukan pemerintahan daerah dalam sistem pemerintahan Negara Kesatuan Republik Indonesia. Negara Indonesia yang menganut susunan negara kesatuan dalam menguraikan sentralitas kekuasaan pusat, membagi wilayah-wilayah dalam bentuk Provinsi, dan Kabupaten/Kota, disamping adanya pemerintahan desa. Proses penguraian kekuasaan ini dalam kajian teoritis tentang pemerintahan daerah di Indonesia pada intinya menekan pada gagasan tentang penyerahan otonomi seluasluasnya pada daerah otonom untuk mengurus rumah tangga berdasarkan prakarsanya sendiri.

Dalam Pasal 18 ayat (2) UUD NRI 1945 disebutkan bahwa Pemerintah daerah Provinsi, daerah Kabupaten, dan Kota mengatur dan mengurus sendiri urusan pemerintahan menurut asas otonomi dan tugas pembantuan. Kemudian pada Pasal 18 ayat (5) disebutkan bahwa pemerintahan daerah menjalankan otonomi seluas-luasnya, kecuali urusan pemerintahan yang oleh undang-undang ditentukan sebagai urusan Pemerintahan Pusat. Mengenai istilah otonomi, Undang-Undang Nomor 23 tahun 
2014 sebagaimana telah diubah dengan Undang-Undang Nomor 9 tahun 2015 tentang Perubahan Kedua Atas Undang-Undang Nomor 23 tahun 2014 tentang Pemerintahan Daerah (selanjutnya disebut UU Pemda), memberikan pengertian tentang istilah otonomi daerah adalah hak, wewenang, dan kewajiban daerah otonom untuk mengatur dan mengurus sendiri urusan Pemerintahan dan kepentingan masyarakat setempat dalam sistem Negara Kesatuan Republik Indonesia. Sedangkan asas otonomi adalah prinsip dasar penyelenggaraan pemerintahan daerah berdasarkan otonomi daerah.

Ketentuan mengenai pengaturan tentang daerah-daerah yang diberi pijakan konstitusionalitas juga menyangkut sifat dari daerah itu sendiri. Dalam Pasal 18A ayat (1) UUD NRI 1945, disebutkan bahwa hubungan wewenang antara pemerintah pusat dan pemerintahan daerah Provinsi, Kabupaten, dan Kota, atau Provinsi dan Kabupaten dan Kota, diatur dengan Undang-Undang dengan memperhatikan kekhususan dan keragaman daerah. Kemudian pada Pasal 18B ayat (1) disebutkan bahwa Negara mengakui dan menghormati satuan-satuan pemerintahan daerah yang bersifat khusus atau bersifat istimewa yang diatur dengan undang-undang (kursif oleh penulis). Pasal ini yang menjadi dasar pelaksanaan penyelenggaraan pemerintahan daerah yang bersifat khusus atau istimewa, termasuk di Papua dan Papua Barat.

Dalam Penjelasan UU Otsus (vide, Penjelasan UU Nomor 21 tahun 2001) dijelaskan bahwa :

“Otonomi Khusus bagi Provinsi Papua pada dasarnya adalah pemberian kewenangan yang lebih luas bagi Provinsi dan rakyat Papua untuk mengatur dan mengurus diri sendiri di dalam kerangka Negara Kesatuan Republik Indonesia. Kewenangan yang lebih luas berarti pula tanggung jawab yang lebih besar bagi Provinsi dan rakyat Papua untuk menyelenggarakan pemerintahan dan mengatur pemanfaatan kekayaan alam di Provinsi Papua untuk sebesarbesarnya bagi kemakmuran rakyat Papua sebagai bagian dari rakyat Indonesia sesuai dengan peraturan perundang-undangan. Kewenangan ini berarti pula kewenangan untuk memberdayakan potensi sosial-budaya dan perekonomian masyarakat Papua, termasuk memberikan peran yang memadai bagi orangorang asli Papua melalui para wakil adat, agama, dan kaum perempuan. Peran yang dilakukan adalah ikut serta merumuskan kebijakan daerah, menentukan strategi pembangunan dengan tetap menghargai kesetaraan dan keragaman 
kehidupan masyarakat Papua, melestarikan budaya serta lingkungan alam Papua, yang tercermin melalui perubahan nama Irian Jaya menjadi Papua, lambang daerah dalam bentuk bendera daerah dan lagu daerah sebagai bentuk aktualisasi jati diri rakyat Papua dan pengakuan terhadap eksistensi hak ulayat, adat, masyarakat adat, dan hukum adat."

Selanjutnya dijelaskan pula mengenai hal-hal mendasar yang menjadi isi Undang-Undang ini adalah, Pertama, pengaturan kewenangan antara Pemerintah dengan Pemerintah Provinsi Papua serta penerapan kewenangan tersebut di Provinsi Papua yang dilakukan dengan kekhususan; Kedua, pengakuan dan penghormatan hak-hak dasar orang asli Papua serta pemberdayaannya secara strategis dan mendasar; dan Ketiga, mewujudkan penyelenggaraan pemerintahan yang baik yang berciri: (a) partisipasi rakyat sebesar-besarnya dalam perencanaan, pelaksanaan dan pengawasan dalam penyelenggaraan pemerintahan serta pelaksanaan pembangunan melalui keikutsertaan para wakil adat, agama, dan kaum perempuan; (b) pelaksanaan pembangunan yang diarahkan sebesar-besarnya untuk memenuhi kebutuhan dasar penduduk asli Papua pada khususnya dan penduduk Provinsi Papua pada umumnya dengan berpegang teguh pada prinsip-prinsip pelestarian lingkungan, pembangunan berkelanjutan, berkeadilan dan bermanfaat langsung bagi masyarakat; dan (c) penyelenggaraan pemerintahan dan pelaksanaan pembangunan yang transparan dan bertanggungjawab kepada masyarakat. Keempat, pembagian wewenang, tugas, dan tanggung jawab yang tegas dan jelas antara badan legislatif, eksekutif, dan yudikatif, serta Majelis Rakyat Papua sebagai representasi kultural penduduk asli Papua yang diberikan kewenangan tertentu.

Pengaturan kewenangan antara Pemerintah dengan Pemerintah Provinsi Papua serta penerapan kewenangan tersebut di Provinsi Papua yang dilakukan dengan kekhususan tertuang dalam Pasal 4 UU Otsus. Disebutkan dalam Pasal tersebut bahwa Kewenangan Provinsi Papua mencakup kewenangan dalam seluruh bidang pemerintahan, kecuali kewenangan bidang politik luar negeri, pertahanan keamanan, moneter dan fiskal, agama, dan peradilan serta kewenangan tertentu di bidang lain yang ditetapkan sesuai dengan peraturan perundang-undangan. Selain itu dalam 
rangka pelaksanaan Otonomi Khusus, Provinsi Papua diberikan kewenangan khusus berdasarkan UU Otsus yang diatur lebh lanjut dengan Perdasus dan Perdasi. Daerah Kabupaten/Kota mencakup pula kewenangan sebagaimana telah diatur dalam peraturan perundang-undangan, disamping juga kewenangan khusus berdasarkan UU Otsus yang diatur pula dalam Perdasus dan Perdasi.

Bentuk dan susunan pemerintahan berdasarkan Pasal 5 UU Otsus, disebutkan bahwa Pemerintahan Daerah Provinsi Papua terdiri atas Dewan Perwakilan Rakyat Papua (DPRP) sebagai badan legislatif, dan Pemerintah Provinsi sebagai badan eksekutif. Disamping itu, dalam rangka penyelenggaraan Otonomi Khusus di Provinsi Papua dibentuk Majelis Rakyat Papua (MRP) yang merupakan representasi kultural orang asli Papua yang memiliki kewenangan tertentu dalam rangka perlindungan hak-hak orang asli Papua, dengan berlandaskan pada penghormatan terhadap adat dan budaya, pemberdayaan perempuan, dan pemantapan kerukunan hidup beragama.

MPR dan DPRP berkedudukan di Ibu Kota Provinsi, bersama-sama dengan Gubernur sebagai pemerintah Provinsi dan perangkat pemerintah Provinsi lainnya. Sedangkan di Kabupaten/Kota dibentuk Dewan Perwakilan Rakyat Daerah (DPRD) Kabupaten dan Dewan Perwakilan Rakyat Daerah (DPRD) Kota sebagai badan legislatif, serta Pemerintah Kabupaten/Kota sebagai badan eksekutif. Pemerintah Kabupaten/Kota terdiri atas Bupati/Walikota beserta perangkat pemerintah Kabupaten/Kota lainnya. Di Kampung dibentuk Badan Musyawarah Kampung dan Pemerintah Kampung atau dapat disebut dengan nama lain.

Disamping hal-hal yang sebagaimana telah diuraikan diatas, kewenangan khusus yang dimiliki oleh Provinsi Papua berdasarkan UU Otsus yang tidak dimiliki oleh daerah lain di Indonesia, dapat dirincikan ke dalam beberapa hal pokok sebagai berikut : (1) Provinsi Papua dapat lambang daerah sebagai panji kebesaran dan simbol kultural bagi kemegahan jati diri orang Papua dalam bentuk bendera daerah dan lagu daerah yang tidak diposisikan sebagai simbol kedaulatan (Pasal 2 ayat 2); (2) Penduduk Provinsi Papua dapat membentuk partai politik (Pasal 28 ayat 1); (3) 
Peraturan Daerah Khusus (Perdasus), adalah Peraturan Daerah Provinsi Papua dalam rangka pelaksanaan pasal-pasal tertentu dalam UU Otsus (Pasal 1 huruf i). Berdasarkan Pasal Pasal 29 ayat (1), Perdasus dibuat dan ditetapkan oleh DPRP bersama-sama Gubernur dengan pertimbangan dan persetujuan MRP; (4) Peraturan Daerah Provinsi (Perdasi), adalah Peraturan Daerah Provinsi Papua dalam rangka pelaksanaan kewenangan sebagaimana diatur dalam peraturan perundang-undangan (Pasal 1 huruf j). Berdasarkan Pasal 29 ayat (2), Perdasi dibuat dan ditetapkan oleh DPRP bersama-sama Gubernur; (5) Badan Musyawarah Kampung (Pasal 1 huruf m), adalah sekumpulan orang yang membentuk satu kesatuan yang terdiri atas berbagai unsur di dalam kampung tersebut serta dipilih dan diakui oleh warga setempat untuk memberikan saran dan pertimbangan kepada Pemerintah Kampung. Sedikit berbeda dengan Badan Permusyawaratan Desa dalam UU nomor 6 tahun 2014, yang kedudukannya sebagai lembaga yang menjalankan fungsi pemerintahan; (6) Orang Asli Papua (Pasal 1 huruf t), adalah orang yang berasal dari rumpun ras Melanesia yang terdiri dari suku-suku asli di Provinsi Papua dan/atau orang yang diterima dan diakui sebagai orang asli Papua oleh masyarakat adat Papua; (7) Dana Otonomi Khusus, yang diuraikan rinciannya dalam Pasal 34; (8) Pembentukan perwakilan Komisi Nasional Hak Asasi Manusia (Komnas HAM), Pengadilan HAM, dan Komisi Kebenaran dan Rekonsiliasi (KKR) di Provinsi Papua sesuai dengan peraturan perundang-undangan.

Hal menarik lainnya dalam penyelenggaraan pemerintahan berdasarkan UU Otsus adalah mengenai Pemekaran Provinsi Papua menjadi provinsi-provinsi dilakukan atas persetujuan MRP dan DPRP, setelah memperhatikan dengan sungguhsungguh kesatuan sosial-budaya, kesiapan sumberdaya manusia dan kemampuan ekonomi dan perkembangan di masa datang (Pasal 76).

\section{Kedudukan dan Penyelenggaraan Pemerintahan Daerah Provinsi Papua Barat Berdasarkan Undang-Undang Nomor 35 Tahun 2008}

Apabila ditelisik lebih jauh secara historis dari segi landasan sosiologis yang tertuang dalam konsideran, pembentukan UU Otsus disusun terkait dengan eksistensi 
wilayah Papua yang belum diadakan pemekaran sehingga substansi yang termuat dalam UU Otsus masih berbicara mengenai Provinsi Papua. Pemekaran wilayah Irian Jaya Barat (Papua Barat) bersama daerah lainnya dibentuk berdasarkan UU Nomor 4 tahun 1999 tentang Pembentukan Provinsi Jaya Barat, Provinsi Irian Jaya Tengah, kabupaten Mimika, Kabupaten Paniai, kabupaten Puncak Jaya, dan Kota Sorong, yang sempat dibatalkan oleh Mahkamah Konstitusi sehingga kehilangan payung hukum namun tetap diakui eksistensinya. Pada tahun 2007, berubah nama menjadi Provinsi Papua Barat berdasarkan Peraturan Pemerintah Nomor 27 tahun 2007 (Sirajuddin, et.al, 2016:279-280).

Untuk memberikan payung hukum terhadap penyelenggaran pemerintahan daerah berdasarkan Otonomi Khusus di wilayah Papua Barat, dibentuklah Peraturan Pemerintah Pengganti Undang-Undang (Perpu) Nomor 1 tahun 2008, dan kemudian disahkan menjadi Undang-Undang Nomor 35 tahun 2008 tentang Penetapan Peraturan Pemerintah Pengganti Undang-Undang Nomor 1 Tahun 2008 Tentang Perubahan Atas Undang-Undang Nomor 21 Tahun 2001 Tentang Otonomi Khusus Bagi Provinsi Papua Menjadi Undang-Undang.

Diskursus hukum terhadap eksistensi penyelenggaraan pemerintahan daerah berdasarkan hak Otonomi Khusus di Papua Barat terkait masalah ketentuan Pasal 1 huruf b UU Otsus, dimana dalam ketentuan tersebut, pengertian Otonomi Khusus tidak secara tegas menyebutkan Provinsi Papua Barat sebagai salah satu Provinsi yang juga diberikan kewenangan khusus dan di akui. Terlepas dari masalah yang demikian, berdasarkan peraturan perundang-undangan, eksistensi Papua Barat dalam penyelenggaran pemerintahan daerah berdasarkan Otonomi Khusus dapat dikatakan telah memenuhi syarat legitimasi, mengingat beberapa aturan perundang-undangan yang berkaitan dengan Otsus telah mengatur beberapa hal pokok tentang penyelenggaraan pemerintahan daerah di Provinsi Papua Barat.

Terkait masalah kedudukan dan penyelenggaraan pemerintahan daerah di Provinsi papua Barat, Pasal 1 huruf a UU Otsus secara atributif telah memberikan kedudukan hukum bagi eksistensi Provinsi Papua Barat yang diberi Otonomi Khusus 
dalam kerangka Negara Kesatuan Republik Indonesia. Sementara itu perihal aturanaturan operasional lainnya yang berkaitan dengan penyelenggaraan pemerintahan daerah berdasarkan Otonomi Khusus, selanjutnya dituangkan dalam Peraturan Pemerintah, Perdasus dan Perdasi, disamping sejumlah peraturan operasional lainnya.

Terkait dengan atribusi, dari segi teori menurut H.D. van Wijk dan Willem Konijnenbelt, sebagaimana dikutip oleh Ridwan HR (2006:102) adalah, toekenning van een berstuursbevoegheid door een wetgever aan een bestuursorgaan (pemberian wewenang pemerintahan oleh pembuat undang-undang kepada organ pemerintahan). Dalam Pasal 1 angka 22 UU Nomor 30 Tahun 2014, dijelaskan bahwa "atribusi adalah pemberian kewenangan kepada badan dan/atau Pejabat Pemerintahan oleh Undang-Undang Dasar Negara Republik Indonesia Tahun 1945 atau UndangUndang”.

Selanjutnya dalam Pasal 12 ayat (1) dijelaskan mengenai perolehan atribusi apabila, (a) diatur dalam UUD NRI 1945 dan/atau Udang-Undang; (b) merupakan wewenang baru atau sebelumnya tidak ada; dan (c) atribusi diberikan kepada Badan/Pejabat Pemerintahan. Ayat (2) menyebutkan, "badan dan/atau pejabat pemerintahan yang memperoleh wewenang atribusi, tanggung jawab kewenangan berada pada badan dan/atau pejabat pemerintahan yang bersangkutan". Dan ayat (3) menyebutkan "kewenangan atribusi tidak dapat didelegasikan, kecuali di dalam UUD NRI 1945 dan/atau Undang-Undang”.

Kerancuan Pasal 1 huruf b UU Otsus yang tidak memuat frasa "Papua Barat" sebagai salah satu Provinsi yang diberi kewenangan khusus, dalam kaidah pembentukan peraturan perundang-undangan memang merupakan masalah tersendiri. Berdasarkan Pasal 5 huruf f UU Nomor 12 tahun 2011 tentang Pembentukan Peraturan Perundang-Undangan, secara tegas disebutkan bahwa salah satu asas pembentukan peraturan yang baik adalah mengenai kejelasan rumusan (kufsif oleh penulis). Disebutkan dalam Penjelasan UU Nomor 12 tahun 2011, yang dimaksud dengan "asas kejelasan rumusan" adalah bahwa setiap Peraturan Perundangundangan harus memenuhi persyaratan teknis penyusunan Peraturan Perundang- 
undangan, sistematika, pilihan kata atau istilah, serta bahasa hukum yang jelas dan mudah dimengerti sehingga tidak menimbulkan berbagai macam interpretasi dalam pelaksanaannya. Jelas bahwa bersadarkan Penjelasan ini, rumusan Pasal 1 huruf $b$ UU Otsus dapat dikatakan belumlah cukup memenuhi kaidah pembentukan perundang-undangan yang baik, walaupun juga tidak buruk sama sekali.

Namun, sejauh mana Pasal 1 huruf b UU Otsus mempengaruhi jalannya penyelenggaraan pemerintahan daerah Provinsi Papua Barat Berdasarkan Otonomi Khusus juga tidak terlalu signifikan, sebab, sebagaimana disebutkan diatas bahwa beberapa hal yang tidak dimuat dalam UU Otsus, dituangkan dalam aturan-aturan dibawahnya. Salah satu hal mendasar dalam penyelenggaraan pemerintahan daerah berdasarkan kewenangan Otonomi Khusus ialah keberadaan MRP sebagai sebuah badan representasi kultural Orang Asli Papua yang kedudukannya berada di Provinsi. Hanya saja, MRP yang dimaksud dalam UU Otsus cenderung mengatur kedudukan MRP di Provinsi papua. Hal ini juga terlihat dari Nomenklatur kelembagaan yang diberikan oleh UU Otsus terhadap MRP, yakni, Majelis Permusyawaratan Papua, tanpa tambahan frasa "barat" untuk eksistensi MRP(B).

Permasalahan tersebut dari segi peraturan perundang-undangan sebenarnya telah teratasi oleh Pasal 74 ayat 1 Peraturan Pemerintah Nomor 54 tahun 2004 tentang Majelis Rakyat Papua yang menyebutkan "Dalam hal pemekaran Provinsi Papua menjadi provinsi-provinsi baru dibentuk MRP, yang berkedudukan di masing-masing ibukota provinsi”, walaupun lagi-lagi dalam Peraturan Pemerintah tersebut tidak terlihat adanya nomenklatur kelembagaan MRP dalam istilah tertentu yang berkaitan dengan wilayah pemekaran baru sebagaimana dimaksud. Akan tetapi, secara umum dapat dipahami bahwa perintah pembentukan MRP di provinsi-provinsi yang baru dibentuk merujuk pada daerah pemekaran yang ada di wilayah Papua (dan/atau Papua Barat).

Hal menarik lainnya dalam penyelenggaraan pemerintahan daerah berdasarkan Otonomi Khusus, yakni mengenai keuangan yang tertuang dalam Bab IX Pasal 33 37. Keuangan daerah dengan Otonomi Khusus juga diatur dalam Bab XIV Ketentuan 
Peralihan Pasal 105 ayat (2) UU Nomor 33 tahun 2004, menyatakan bahwa ketentuan yang mengatur tentang Dana Bagi hasil dalam UU Otsus dinyatakan berlaku selama tidak diatur lain. Hal ini menunjukan bahwa keuangan daerah dalam rangka pelaksanaan kewenangan Otsus Papua dan Papua Barat mengacu pada Bab IX Pasal 33-37, disamping peraturan operasional lainnya. Keberadaan aturan operasional lainnya diperlukan, sebab sebagaimana diketahui bahwa antara Provinsi Papua dan Papua Barat memiliki jumlah penduduk, kontur geografis, kebutuhan dan potensi daerah, dan sebagainya, yang berbeda-beda telah berjalan sebagaimana mestinya.

\section{SIMPULAN}

Berdasarkan uraian diatas, dapat disimpulkan bahwa kerancuan redaksi ketentuan Pasal 1 huruf b UU Otsus berdasarkan kaidah pembentukan peraturanperundang-undangan belumlah dapat dikatakan telah memenuhi kaidah pembentukan peraturan perundang-undangan yang baik. Di lain sisi, kedudukan dan penyelenggaraan pemerintahan daerah Provinsi Papua Barat berdasarkan peraturan perundang-undangan dapat dikatakan legitimatif. Kedudukan Provinsi Papua Barat dalam penyelenggaraan pemerintahan daerah berdasarkan Otonomi Khusus menurut UU Otsus jo. Perpu Nomor 1 Tahun 2008, dalam Konsideran menimbang disebutkan secara tegas bahwa keberadaan Provinsi Irian Jaya Barat yang kemudian berubah menjadi Provinsi Papua Barat, dalam kenyataannya telah menjalankan urusan pemerintahan dan pembangunan serta memberikan pelayanan kepada masyarakat sejak tahun 2003, namun belum diberlakukan Otonomi Khusus berdasarkan UndangUndang Nomor 21Tahun 2001 tentang Otonomi Khusus Bagi Provinsi Papua.

Kerancuan Pasal 1 huruf b UU Otsus dapat diubah berdasarkan ketentuan Pasal 72 Peraturan Pemerintah Nomor 54 Tahun 2004, atau dengan cara membentuk Perpu oleh Pemerintah Pusat.

\section{DAFTAR PUSTAKA}


Agung Djojosoekarto, et.al, 2008, Kebijakan Otonomi Khusus Di Indonesia, Pembelajaran dari Kasus Aceh, Papua, Jakarta, dan Yogyakarta, Kemitraan bagi Pembaharuan Tata Pemerintahan di Indonesia.

Agussalim andi Gadjong, 2007, Pemerintahan Daerah : Kajian politik dan Hukum, Ghalia Indonesia, Bogor.

Amrah Muslimin, 1978, Aspek-Aspek Hukum Otonomi Daerah, Alumni, Bandung. Ateng Syafrudin, 1985, Pasang Surut Otonomi Daerah, Bina Cipta, Bandung.

Bagir Manan, 2001, Menyongsong Fajar Otonomi Daerah, Yogyakarta : Pusat Studi Hukum FH UII, Yogyakarta.

HRT Sri Soemantri, 2014, Otonomi Daerah, Remaja Rosdakarya, Bandung.

Imam Soebechi, 2012, Judicial Review Perda Pajak dan Restribusi Daerah, Sinar Grafika, Jakarta.

Indra J. Piliang, et.al, 2003, Otonomi Daerah : Evaluasi dan Proyeksi, Yayasan Harkat Bangsa, Jakarta.

Josef Riwu Kaho, 1995, Prospek Otonomi daerah di Negara Republik Indonesia : Identifikasi Beberapa Faktor Yang mempengaruhi Penyelenggaraannya, Raja Grafindo Persada, Jakarta.

Ko, Nomura. 2007. Democratisation and Environmental Non-governmental Organisation in Indonesia, Journal of Contemporary Asia, 11, Vol. 37 Issue 4, Abingdon, Oxforshire: 495-517.

Ni'matul Huda, 2005, Pengawasan Pusat Terhadap Daerah dalam penyelenggaraan Pemerintahan Daerah, FH UII Press, Yogyakarta.

Ridwan HR, 2006, Hukum Administrasi Negara, Rajagrafindo Persada, Jakarta.

Riris Katharina, 2017, Deliberative Formulation of Papua Special Autonomy Policy, International Journal of Administrative Science \& Organization, Bisnis \& Birokrasi: Jurnal Ilmu Administrasi dan Organisasi, Volume 24, Number 2.

Sirajuddin, et.al, 2016, Hukum Administrasi Pemerintahan Daerah, Setara Press, Malang.

Syaukani HR, et.al, 2002, Otonomi Daerah Dalam Negara Kesatuan, Pustaka Pelajar, Yogyakarta.

Utang Rosidin, 2015, Otonomi Daerah dan Desentralisasi, Pustaka Setia, Bandung. 